\title{
THE FATE OF GOAT $\times$ SHEEP HYBRID EMBRYOS IN GOATS TREATED PARENTERALLY WITH SHEEP SEMEN
}

\author{
P. T. MaGOVERN \\ Department of Anatomy, Royal Veterinary College, London $\mathcal{N W 1} 0 T U$
}

(Received 7th June 1972)

\begin{abstract}
Summary. Five goats were given intravenous injections of sheep spermatozoa at weekly intervals for 21 weeks before insemination with sheep semen. The treatment had no detectable effect on the conception rate. Four of the goats were found to be pregnant when examined at laparotomy or autopsy but there was no evidence of any substantial prolongation of the survival of the hybrid embryos.
\end{abstract}

\section{INTRODUCTION}

Although failure of fertilization and embryonic death prevent successful hybridization of domestic sheep and goats, Bratanov \& Dikov $(1960,1962)$ not only claim to have obtained live hybrids from sheep and goats which had been subjected to repeated injections of heterologous blood or to repeated inseminations with heterologous semen before mating, but also to have obtained a second $\left(F_{b}\right)$ generation of hybrids by backcrossing the $F_{1}$ females to males of the parent species. More recently, Bratanov, Dokov \& Somlev (1969) have published results of a karyological study of an $F_{b}$ hybrid produced by an ovid (sheep $\times$ goat hybrid) which had been back-crossed with a male sheep; the modal chromosome number is given as fifty-five, comprising fifty-one acrocentric and four metacentric chromosomes. In view of suggestions that immunological mechanisms are implicated in the gestational failure of the goat $x$ sheep cross (Sokolovskaja, 1938, 1940; Alexander, Williams \& Bailey, 1967; Alexander \& Williams, 1968; Hancock, McGovern \& Stamp, 1968; Dent, McGovern \& Hancock, 1971; McGovern, 1973), it seemed important to examine the possibility that prolonged treatment with paternal antigen might in some way modify the maternal response to the hybrid embryo. The experiment described below was designed with the particular possibility in mind that immunological tolerance or enhancement might explain survival of hybrids in mothers receiving parenteral injections of heterologous cells.

\section{MATERIALS AND METHODS}

The animals used were six crossbred female goats and a Scottish Blackface ram. Semen was collected with an artificial vagina or by electroejaculation. The 
semen was homogenized and suspended in Tyrode's solution before use. Each goat received an equivalent of 1.66 (range 0.44 to 1.83 ) $\times 10^{9}$ spermatozoa by intravenous injection at weekly intervals for 21 weeks. This route was chosen because there is evidence that immunological tolerance is more likely to occur following administration of antigen intravenously than by other routes (Billingham \& Sparrow, 1955; Snell, Smith \& Fink, 1955).

At the end of the 21-week period, five of the treated animals showed heat and were inseminated on the 1st and 2nd days of oestrus with semen from the same ram.

\section{RESULTS}

Judged by their failure to return to service, four goats appeared to conceive to their first insemination; the fifth goat conceived to insemination at the following oestrus. Pregnancy was confirmed in four of the goats at laparotomy or autopsy. In three goats examined at laparotomy 64,73 and 74 days after insemination, there were clear signs of a terminated pregnancy. The uterine horns were enlarged and contained some fluid but the cotyledons were inconspicuous and no embryo was palpable through the uterine wall. There was no evidence that the embryos had survived beyond the 6th week, when death of the hybrid embryo normally occurs (Hancock et al., 1968). The fourth goat was examined at autopsy 66 days after insemination. The cotyledons were well developed but abnormal in appearance; they were irregular in outline and had large areas of haemorrhage. The embryo was dead and contained a large volume of bloodstained exudate in the peritoneal cavity. The size of the embryo (crown-rump length, $11.0 \mathrm{~cm}$ ) suggests that it was alive until within a few days of autopsy. The growth rate of hybrid embryos up to the 6th week of gestation (Hancock et al., 1968) is similar to that recorded for sheep embryos by Cloete (1939) and by extrapolation from these data, the death of the embryo is estimated to have occurred after Day 60.

\section{DISGUSSION}

The experiment recorded here failed to show any substantial prolongation of the survival of goat $\times$ sheep hybrid embryos in goats which had received repeated injections of sheep spermatozoa. Although one embryo survived to at least 60 days, its longevity cannot, with any certainty, be attributed to the treatment received by the mother since live hybrid embryos of similar gestational age have been recovered from untreated goats by Warwick \& Berry (1949), Lopyrin \& Loginova (1953) and Cooper, Bailey, Alexander \& Williams (1967). The findings do not, of course, refute the claims of Bratanov \& Dikov $(1960,1962)$ since the treatment used differed from the procedure advocated by the Bulgarian workers, but attempts by other workers to confirm these claims have not been successful. Alexander \& Williams (1968) found no evidence that survival of hybrid embryos was prolonged in goats which had received repeated intramuscular or intravenous injections of sheep blood. In the reciprocal cross, experiments have failed to reveal any improvement in fertilization rate follow- 
ing repeated treatment of ewes with heterologous semen by the vaginal route; and of four treated ewes which received hybrid zygotes by surgical transfer, none produced young (H. L. Buttle and J. L. Hancock, unpublished observations).

In view of the above findings, it is unfortunate that the karyological studies by Bratanov et al. (1969) should fail to provide unequivocal identification of the alleged hybrids and thus resolve the uncertainty concerning the value of their methods. The karyotype of the $F_{1}$ goat $x$ sheep hybrid embryo comprises fiftyfour acrocentric and three metacentric chromosomes, being intermediate between that of the goat which comprises sixty acrocentric chromosomes and that of the sheep which comprises forty-eight acrocentric and six metacentric chromosomes (Buttle \& Hancock, 1966). Dain (1970) has concluded that, in addition to other translocations which may have occurred during the evolution of the two species, the metacentric chromosomes of the sheep have arisen by Robertsonian fusion and are represented in the karyotype of the goat by six

Table 1. Theoretical chromosome constitution of the gametes of a sheep-goat hybrid and of the $F_{b}$ generation resulting from backcrossing with sheep

\begin{tabular}{c|c|c|c}
\hline \multicolumn{2}{c|}{$F_{1}($ sheep-goat $)$ hybrid } & \multicolumn{2}{c}{$F_{\mathbf{b}}\left(F_{1} \times\right.$ sheep $)$ hybrid } \\
\cline { 2 - 3 } \multicolumn{1}{c|}{ Karyotype } & Gametes & Karyotype & $2 n$ \\
\hline & $24 \mathrm{~A}+\mathrm{M}+\mathrm{M}+\mathbf{M}$ & $48 \mathrm{~A}+6 \mathrm{M}$ & 54 \\
& $24 \mathrm{~A}+\mathrm{M}+\mathrm{M}+2 \mathrm{~A}$ & & \\
$24 \mathrm{~A}+\mathrm{M}+\mathrm{M}+\mathrm{M}$ & $24 \mathrm{~A}+\mathrm{M}+2 \mathrm{~A}+\mathrm{M}$ & $50 \mathrm{~A}+5 \mathrm{M}$ & 55 \\
$24 \mathrm{~A}+2 \mathrm{~A}+2 \mathrm{~A}+2 \mathrm{~A}$ & $24 \mathrm{~A}+2 \mathrm{~A}+\mathrm{M}+\mathbf{M}$ & & \\
& $\begin{array}{l}24 \mathrm{~A}+\mathrm{M}+2 \mathrm{~A}+2 \mathrm{~A} \\
24 \mathrm{~A}+2 \mathrm{~A}+\mathrm{M}+2 \mathrm{~A}\end{array}$ & $52 \mathrm{~A}+4 \mathrm{M}$ & 56 \\
& $24 \mathrm{~A}+2 \mathrm{~A}+2 \mathrm{~A}+\mathrm{M}$ & & \\
& $24 \mathrm{~A}+2 \mathrm{~A}+2 \mathrm{~A}+2 \mathrm{~A}$ & $54 \mathrm{~A}+3 \mathrm{M}$ & 57 \\
\hline
\end{tabular}

$\mathrm{A}=$ acrocentric chromosome; $\mathrm{M}=$ metacentric chromosome.

pairs of acrocentric chromosomes. It may be assumed, therefore, that the hybrid karyotype comprises twenty-four pairs of acrocentric chromosomes and nine unpaired chromosomes, three metacentric chromosomes of sheep origin and six acrocentric chromosomes of goat origin. In order for meiosis to be completed successfully in the sheep-goat hybrid, it seems probable that the unpaired chromosomes would form three trivalents; there would be synapsis of the twenty-four pairs of acrocentric chromosomes, and each of the metacentric chromosomes of sheep origin would synapse with two acrocentric chromosomes of goat origin. Assuming that the formation of the trivalents is followed by an orderly segregation of the chromosomes and the eventual production of genetically balanced gametes, it is possible to calculate four main arrangements for the chromosomes of the gametes (Table 1) so that the $F_{b}$ generation resulting from back-crossing with sheep would contain individuals with chromosome numbers of 54, 55, 56 or 57 having, respectively, six, five, four or three metacentric chromosomes. 
It is clear that the karyotype of the $\mathrm{F}_{\mathrm{b}}$ hybrid presented by Bratanov et al . (1969) differs from the above theoretical values, possibly because the chromosomes in the metaphase figure depicted are not spread sufficiently well to allow an accurate evaluation of the karyotype to be made. Moreover, although there is evidence that the formation of trivalents may substantially increase the incidence of non-disjunction (Tettenborn \& Gropp, 1970), this would not explain the fact that compared to the two parent species and to the $F_{1}$ hybrid, all of which have a fundamental number of 60 , the $F_{b}$ hybrid, with a fundamental number of 59 , is apparently monosomic, a condition which normally results in early death of the zygote.

The treatment of goats with heterologous semen had no detectable effect on the conception rate. Some of the factors which influence the degree to which parenteral treatment of females with semen may affect fertilization rate have been discussed by Bell (1969), who showed that there was an adverse effect on fertilization when mice were immunized by the intraperitoneal route but not when the vaginal route was used. In cattle, fertility was found to be reduced as the result of intradermal injections of semen and Freund's adjuvant (Menge, 1969) but cattle which received intravenous injections of semen alone showed no impairment of fertility (Kiddy, Stone, Tyler \& Casida, 1959). The lack of any adverse effect on conception rate in the goats treated with sheep semen may not necessarily be related to the chosen route of administration since Goel, Soni \& Bhalla (1969) have found that the conception rate following natural matings was normal in goats hyperimmunized by subcutaneous injections of goat and cattle semen with adjuvant, despite the presence of circulating antibodies.

\section{ACKNOWLEDGMENT}

This work was supported by a grant to Professor J. L. Hancock from the Agricultural Research Council.

\section{REFERENGES}

AleXander, G. \& Williams, D. (1968) Failure of sheep $\times$ goat hybrid foetuses to survive in goats treated with sheep's blood. Aust. F. biol. Sci. 21, 953.

Alexander, G., Williams, D. \& Bailey, L. (1967) Natural immunization in pregnant goats against red blood cells of their sheep $\times$ goat foetuses. Aust. F. biol. Sci. 20, 1217 .

BELL, E. B. (1969) Immunological control of fertility in the mouse: comparison of systemic and intravaginal immunization. F. Reprod. Fert. 18, 193.

Billingham, R. E. \& Sparrow, E. M. (1955) The effect of prior intravenous injections of dissociated epidermal cells and blood on survival of skin homografts in rabbits. J. Embryol. exp. Morph. 3, 265.

Bratanov, G. \& Dikov, V. (1962) Fécondation entre les espèces brebis et chères et obtention d'hybride interespeces. In: Proc. 4th Int. Congr. Anim. Reprod., The Hague, Vol. IV, p. 744.

Bratanov, K. \& Dikov, V. (1960) Sheep and goat crossbreds. C.r. Acad. bulg. Sci. 13, 223.

Bratanov, K., Dokov, V. \& Someev, B. (1969) Research on the karyotype of ovids. Genet. E Sel. 2, 363 (title in translation).

Buttle, H. L. \& Hancock, J. L. (1966) The chromosomes of goats, sheep and their hybrids. Res. vet. Sci. 7, 230.

Gloete, J. H. L. (1939) Prenatal growth in merino sheep. Onderstepoort F. vet. Sci. Anim. Ind. 13, 417.

Cooper, D. W., Bailey, L. F., Alexander, G. \& Williams, D. (1967) Serum transfers of twin sheepgoat hybrids. Aust. 7. biol. Sci. 19, 1175.

Dars, A. R. (1970) Separating the sheep from the goats on the basis of their chromosomes. Nature, Lond. 228,560 . 
Dent, J., McGovern, P. T. \& Hancock, J. L. (1971) Immunological implications of ultrastructural findings on goat $\times$ sheep hybrid placentae. Nature, Lond. 231, 116.

Goel, V. D., Soni, B. K. \& Bhalla, R. C. (1969) Fertilization in female goats hyperimmunized with semen antigens. Br. vet. F. 124, 403.

Hancock, J. L., McGovern, P. T. \& Stamp, J. T. (1968) Failure of gestation of goat $x$ sheep hybrids in goats and sheep. F. Reprod. Fert. Suppl. 3, 29.

Kiddy, C. A., Stone, W. H., Tyler, W. J. \& Casida, L. E. (1959) Immunological studies on fertility and sterility. III. Effect of immunization with blood and semen on fertility in cattle. F. Dairy Sci. $42,100$.

Lopyrin, A. I. \& Loginova, N. V. (1953) Remote hybridization of animals. Usp. sovrem. Biol. 36, 227. (Anim. Breed. Abstr. 20, No. 1019).

McGovern, P. T. (1973) The effect of maternal immunity on the survival of goat $\times$ sheep hybrid embryos. F. Reprod. Fert. 34, 217.

Menge, A. C. (1969) Early embryo mortality in heifers iso-immunized with semen. F. Reprod. Fert. 18, 67.

SNELl, G. D., SMith, P. \& Fink, M. A. (1955) An enhancement of tumour homiotransplants in mice produced by the intravenous injection of donor whole blood. Proc. Am. Ass. Cancer Res. 2, 47 (Abstr.).

Sokolovskaja, I. I. (1938) Serological investigations in connection with distant hybridization. Izv. Akad. Nauk. SSSR Otd. mat.-est. Ser. biol. 1938, 947 (title in translation).

SoxolovskAJA, I. I. (1940) The application of serological methods in investigations of incompatibility in distant crosses. Trudȳ Inst. Genet. 13, 249. (Anim. Breed. Abstr. 10, 204).

TetTENBORN, U. \& GROPP, A. (1970) Meiotic nondisjunction in mice and mouse hybrids. Cytogenetics, 9, 272.

WARWICK, B. L. \& BERRY, R. O. (1949) Inter-generic and intra-specific embryo transfers in sheep and goats. F. Hered. 40, 297. 